\title{
Idealism and Indian philosophy
}

\author{
Shyam Ranganathan
}

\section{Introduction}

In the Western tradition, Idealism strikes a contrast with materialism, probably because of the historic contrast between the body and the mind (soul) (Lorenz, 2009), especially as taken up by Plato in dialogues such as the Phaedo. Materialism (as a position about metaphysics and not as a position on social explanation, as we find, say, in Marx and Engels) is the position that corresponds to the priority given to the bodily and the extended (often called physicalism these days) and idealism to the priority given to the mind and the mental. In this tradition, it seems like these are exclusive disjunctions: reject one, and one has to (by way of disjunctive syllogism) affirm the other. Hence, for instance, Keith Ward, enthusiastic adopter of Indian philosophy and idealism, argues that if we reject materialism, we are committed to idealism. He adds that the idea that ultimate reality is mental finds support in the philosophies of India, especially philosophies rooted in the Upaniṣads - philosophies called Vedānta. He also seems to think that all these positions are monistic (Ward, n.d.). Ward's view is remarkably mistaken as a historical account of Indian philosophy. Vedānta is not monism (there are a diversity of positions that are versions of Vedānta, some monistic, some pluralistic), and it is not at all obvious that prominent versions of Vedānta endorse idealism. For instance, Rāmānuja, perhaps the most influential of Vedānta philosophers (Potter, 1963: pp. 252-253), argues for an organic picture of reality, according to which there is an ultimate Self, and we as individual selves, along with inanimate objects, comprise the body of this ultimate Self. If materialism is a bodily explanation of reality, 
Rāmānuja's view is a kind of materialism. But there are further logical problems with Ward's account.

First, materialism and idealism are not contradictories, but contraries, and rejecting materialism does not entail idealism - there (could be) are other options. For instance, one could take the position that practical rationality, or the ethical, is fundamental to reality, and mind and body are natural elements of life to be constrained according to rational choice. This is the view we find in Patañjali's Yoga Sütra (Ranganathan, 2017a), and something like it is to be found in Indian traditions of philosophy that give pride of place to meditation. Secondly, in the Indian tradition, both the mind and the body tend to be subsumed under the realm of nature - the realm of causality. Indian philosophers quite often contrasted causality (in metaphysics) or causal explanations (in epistemology) on the one hand with evaluative (teleological) or normative (procedural) explanations on the other. (One finds this in traditions such as Buddhism and yoga, which distinguish between psychological propensities, samskāra-s, and ethical considerations.) Whereas the arrow of influence in the realm of the causes is from the outside in (causes impinge on the caused), a life lived on the basis of value and especially responsibility reverses the order of explanation - from inside out. Freedom, mokșa, becomes a driving concern as a way to cash out what a life lived on the basis of value looks like: this is a life free from (natural) causal coercion known as samsāra. In drawing a principled distinction between the natural and the normative, Indian philosophers had a way to consider a variety of explanation that was not materialistic nor idealist, but was axiological.

Our investigation tells a very different story of Indian philosophy from the usual myths. According to the myth, Indian philosophers were primarily interested in explaining reality as a kind of (subjective) mental phenomenon, and they were correlatively uninterested in practical, ethical matters. In the next section, we will find that the usual highly Orientalist story of Indian philosophy is a function of a marked departure from basic norms of logic. When we return to logic and see the ubiquitous ethical concern of Indian philosophy, we also see that the dominant criticism of ordinary life by such philosophers is that it is constituted by the psychology of 
individuals, creating a realm of psychological truths that are distinct from absolute facts. If we view this as a criticism, it is clear that the idealist gloss on ordinary experience is critical and constitutes an error theory. But if we ignore the critical context of the psychological diagnosis of mundane facts, it seems like Indian philosophers were defending idealism.

In the third section, we will visit positions that are usually presented as exemplars of Indian idealism. Against the background of a full appreciation of the diversity of moral philosophical disagreement in the Indian tradition, we see that these positions are error theories not accounts of reality or knowledge. These exemplars hence make a case not for idealism but rather ironic idealism: idealism as an error theory. The salient examples of idealism, such as Yogācāra Buddhism, Śañkara’s Advaita Vedānta, Kāśmīra Śaivism, and the Yogavāsiștha, exemplify the trend of ironic idealism. The main element of ironic idealism, ignored in ordinary accounts, is that ironically idealist positions are committed to an account of reality that is not captured by a psychological depiction of ordinary experience.

In the fourth section, I consider some objections. In the fifth section, I conclude by observing that ironic idealism may be a form of idealism, but with some caveats.

\section{Orientalism and irrationality}

I am a philosopher by profession and training. But I fell in love with philosophy as an undergraduate. Its chief virtue that it convinced me of back then was that it allows us to participate in an exercise of understanding without having to buy any party line or background position. We can be entirely agnostic as we learn about the great diversity of philosophical positions. If we want a historical example of this activity, we could look to Socrates's interactions with interlocutors that he disagreed with: his method was, in general, to render explicit his interlocutor's theory about some controversial conclusion as a condition of further discussion. I took to this like a house on fire. What I learned to do (quickly) was to take on the responsibility of rendering explicit the reasons that philosophers have for their controversial 
conclusions and further understand the topics of debate as what the controversy is about. And this was and is made possible by formal reason, whether deduction, induction, or abduction something much clearer to me now as I teach critical thinking and basic logic to undergraduates. All forms of reason involve drawing a distinction between truth and reason, for reason is about inferential support for conclusions, and that is something entirely independent of the truth of premises and conclusions. Bad arguments can be comprised entirely of true premises and a true conclusion, and good arguments can be comprised of false premises that inferentially support a false conclusion.

Now, I formulate this procedure of using logic to understand philosophy as explication. To explicate a perspective $P$ - augustly called a philosophy - about topic $t$, is to $E$ :

- Discern the reasons of $P$ that constitute $P$, which entail $P$ 's use of ' $t$ ' and to arrive at a systematization of $P$ 's reasons that entails the uses of ' $t$.' The systematization of $P$ 's reasons that entails $P$ 's $t$-claims is $P$ 's theory of $t$. The reasons of $P$ may be what $P$ explicitly says or what is entailed by $P$.

The idea of entailment is the idea of validity: an argument is valid if the conclusion has to be true given the truth of the premises. Validity is the standard of inferential support appropriate for deductive arguments. To explicate, hence, one has to be able to reason formally as per the requirements of deduction. This is the first step. This is when we look to a perspective to provide the reasons that entail its use of a controversial term, like 'dharma' or 'morality.' Its reasons are its theory of dharma or morality. Then there is the second step:

- Compare theories of $t$ : what they converge on while they disagree is the concept $T$.

We could call this second step the consilience of entailments. In short, 
- Explication is the explanation of a perspective in terms of its entailed theories that entail the perspective's controversial claims.

Explication is a skill that takes work to develop. However, I discovered early that with this approach, I could pick up any work of philosophy, regardless of the tradition (analytic, continental, Indian, Chinese ...) and understand what the philosopher was trying to get at and how they were contributing to wider disagreements in philosophy. Moreover, while this is a difficult skill to manage, it is not impossible, and it allows for a certain variety of criticism. For having explicated a position, we can tell whether the explicated theory relies upon suppressed or assumed premises or whether a full explication of the theoretical requirements to get a conclusion off the ground violates basic requirements of reason (inferential support) or involves some type of tension in the work of the philosopher themselves. This variety of formal criticism does not beg questions (for it assumes no substantive commitment that the explicated has to agree to), nor does it follow from the substantive beliefs of the explicator as a deductive entailment. This is important: an explicated position is a practical outcome of employing explication, but it is not a deductive entailment of explication (the procedure listed earlier). So, for instance, if using this methodology, we render explicit Plato's theory of the Forms, this theory is not true in virtue of the truth of explication. (If it were, it would be a deductive entailment of explication.) Explication is hence content neutral and can be used to explicate any position, and the resulting explicated positions do not question-beggingly follow from the method of explication.

Employing explication helps us distinguish two varieties of claims:

- $\quad p$ (e.g., 'A valid argument is an argument such that if the premises are true, the conclusion has to be true'); and

- $\quad x$ believes that $p$ (e.g., 'I believe that a valid argument is an argument such that if the premises are true, the conclusion has to be true'). 
The truth conditions of these two claims are different. In the case of $p$, it is true just in case $p$, and $x$ believes $p$ is true just in case $x$ believes $p$. So $p$ may be false, or we may not know whether it is true, and yet it may be true that $x$ believes $p$. Explication allows us to track propositions as playing a role in inferential explanations and allows us to leave aside whether anyone actually believes it, which is a different question altogether. As Socrates often demonstrates in Plato's Socratic dialogues, someone's fully explicated theory may not be anything they want to endorse (once it's all rendered explicit). As a matter for our later investigation into Indian philosophy and idealism, it is worth noting that:

- If you were to confuse these two varieties of claims, you would collapse thinking $p$ with mental attitudes such as believing $p$, and then you might be inclined to treat thought itself as evidence of idealism, for anything thinkable would hence seem reducible to some mental attitude towards such propositions.

If a fact is merely a true thought (cf. Frege, 1988: p. 51), then conflating the fact that $p$ with $x$ believing that $p$ would provide grounds for idealism, for reality would apparently be reducible to $x$ 's mind in so far as $x$ 's beliefs are reducible to $x$ 's mind. This is important, given two related definitions of idealism, as per the Stanford Encyclopedia of Philosophy. Idealism could entail either:

something mental (the mind, spirit, reason, will) is the ultimate foundation of all reality, or even exhaustive of reality, or although the existence of something independent of the mind is conceded, everything that we can know about this mind-independent 'reality' is held to be so permeated by the creative, formative, or constructive activities of the mind (of some kind or other) that all claims to knowledge must be considered, in some sense, to be a form of self-knowledge. 
If the fact that $p$ were reducible to $x$ 's belief that $p$, we could see how both varieties of idealism arise. The first kind arises because the facts of $p$ are reduced to the mental belief that $p$. In the second approach, even if we allow for the proposition $p$ to have a distinct, non-mental existence, the fact that it has to be known via $x$ 's belief that $p$ suggests that our knowledge of $p$ is permeated by our believing it, and a transparent account of knowledge would be a variety of self-knowledge in which we understand what it is that we believe. Yet idealism so generated by this reduction would be ironic, as $x$ believes that $p$ is parasitic on $p$, and the truth conditions are correspondingly distinct.

And indeed, when we come to the Indian tradition, we find that there was a long tradition of yoga (meditation) geared towards drawing distinctions between thinking and believing (Yoga Sūtra, I.2-3). And indeed, Indian philosophers had their own way of distinguishing between $p$ and $x$ believes that $p$. This is the age-old distinction between absolute truth or paramārtha satya (p) and conventional, provisional, or worldly truth, saṁvrti or vyāvahārika satya (x believes that $p)$. Absolute truth, say the fact of $p$, is the simpler, non-agent relative truth, so it is, in this sense, absolute, while $x$ believes that $p$ is provisional and dependent upon worldly contingencies, like $x$ believing $p$. But, importantly, this contingent variety of truth creates a world where agents act in accordance with such beliefs, thereby reifying their choices to believe $p$ as though it were an absolute fact, when it isn't. So we might end up constructing a world that reflects the belief that $p$ (a proposition about gender or caste superiority, for instance) while $p$ itself may not be absolutely true. Not $p$ may be the absolute truth.

Some have glossed this as an essentially Buddhist distinction (Thakchoe, 2011), but it is as old as the Vedas and common to Indian schools of philosophy that disagreed about the contents of both varieties of truth. It is, for instance, an important part of the positions that we will investigate as ironically idealistic. But notice it's not surprising that Indian philosophers drew such a distinction as it's a logical distinction between the two varieties of claims. What is remarkable is that they are not ubiquitously drawn and that the two categories can be collapsed. (We shall see: there is an explanation for this that is part philosophical and part cultural.) 
In contrast to my chosen method of explication that I learned from philosophers past and present, there were bad students of philosophy (most of my peers) who did not explicate. They rather tried to understand everything they read as a deductive entailment of their own substantive beliefs. So reading Plato, they would hence try to replace Plato's arguments with what they would say on a case-by-case basis. So if Plato said the forms were more real than objects of experience, they would replace this claim with how they would describe experience and categories. These folks could hence only make sense of something that agreed with their perspective. Otherwise, they had a fragmented and frustrating experience with philosophy, for in replacing Plato's arguments with what they would in each case, premise by premise, say, the result was not a retelling of their own worldview, nor an understanding of Plato's theory, but a fragmentation of their own perspective by way of Plato's theoretical inferences. However, every fragmented outcome of this interpretation would be a deductive entailment of the interpreter's own beliefs. Formalized, these unsuccessful students of philosophy engaged in what we might call interpretation. To interpret some package $P$ is for the interpreting subject $S$ to $I$ :

- Use $S$ 's reasons (or if you prefer, 'premises,' 'assumptions,' 'beliefs,' 'truths,' and even 'tradition') $r_{\mathrm{S}}$ in the explanation of $P$.

In short:

- Interpretation is the explanation deduced from the beliefs of the interpreter.

Interpretation constitutes a misuse of logic. When we reason deductively, for instance, we gauge whether a conclusion has to be true if the premises are true: if this is the case, the conclusion follows from the premises. But, of course, an argument that is valid need not be sound (contain true premises), and an invalid argument can be composed entirely of true premises and a true conclusion. So truth is entirely inessential to reason. (The same goes for induction, in which arguments can be strong without being cogent (based on credible evidence), and abduction, in 
which the best explanation need not be the true one, merely better than the alternatives.) Yet interpretation makes the acceptability of an explanation contingent upon what the interpreter takes to be true, so it violates very basic constraints of reason. And this violation is of the essence of confusing two varieties of claims as noted earlier: the absolute and the provisional sort, with the result that all explanation is explanation by way of the provisional commitments of the interpreter. So even though the outcome of an interpretation is an entailment of the beliefs of the interpreter, the expectation that one's beliefs must be the premise of an acceptable explanation is literally illogical. Anything and everything that issues from someone committed to this methodology is literal illogic. And hence, if they should object to this analysis on the basis of interpretation, it would be illogic.

After an MA in philosophy I pursued an MA in South Asian Studies to give myself more information and room to decide what to pursue as doctoral research. There, I discovered two remarkable outrages. If authors in Indology explicated Indian philosophy, they would find that the main historical disagreement across competing schools of thought was a disagreement about dharma, which amounts to a disagreement about THE RIGHT OR THE GOOD. Various uses of 'dharma' across traditions would hence be entailed by each tradition's theory of dharma, and the concept of DHARMA would be fixed as the topic of disagreement. Explicated, disagreements about ethics or morality would similarly be shown to be a disagreement about THE RIGHT OR THE GOOD, and hence dharma philosophy is India's ancient and persistent exploration of moral philosophy. But no one had attempted this. Rather, the common orthodoxy was that 'dharma' is a term with many meanings, and each meaning was whatever the Indologist was willing to say when an Indian thinker used the word 'dharma.' In other words, the exact method that is not tolerated or successful in philosophy as a means of understanding - what characterizes bad students of philosophy: namely, interpretation - is the default approach to the study of Indian thought. But this was and is correlated with the second outrage: the widespread conviction that the Indian tradition is bereft of any significant tradition of moral philosophy. In the words of Bimal Matilal, a leading author on Indian thought, 
[E]xcept some cursory comments and some insightful observations, the professional philosophers of India have very seldom discussed what we call 'moral philosophy' today. It is true that the Dharmaśāstra texts were there to supplement the Hindu discussion of ethics; classification of virtues and vices, and enumeration of duties related to the social status of the individual. But morality was never discussed as such in these texts.

\section{(Matilal, 1989: p. 5)}

If we try to interpret Indian thought, and the moral theories of Indian philosophers diverge from the ones we use as the basis of our interpretation, we will find no moral philosophy there. Correlatively, if we explicate Indian philosophy, we find an extensive disagreement on moral philosophy across theories of dharma. Even as recently as my 2017 Bloomsbury Research Handbook of Indian Ethics, the interpretive approach to 'dharma' and the negative conclusions about the place of moral theorizing in the Indian tradition continued to be the dominant approach. (For a recent review of the literature, please see Ranganathan, 2017b: pp. 52-55.)

What I share here is a reconstruction (minus all the time-consuming confusion) of years of research, spanning my time as a graduate student and my first decade as a junior scholar, with $\mathrm{PhD}$ in hand. There were observations that I didn't know what to do with until the methodological distinction between explication and interpretation started falling in place in my own research. The first such observation was that most scholars writing on Indian philosophy were not actually philosophers, but usually philologists, Sanskritists, and historians. Hence (as a review of recent issues of the Journal of Indian Philosophy will show), philology and the study of Sanskrit literature will often pass for the study of Indian philosophy. This is strange: being an English lit major or historian of the UK does not count as credentials for writing on Russell and Moore, yet being a Sanskritist or historian of South Asia is widely believed to be credential enough to write on Indian philosophy (?). The second observation is that this tendency to endorse interpretation (when confronted with a choice between it and explication) seemed to correlate 
with being a philologist or Sanskritist while presuming to have the research skills required to study Indian philosophy. And correlatively, I found that those who identified more as a philosopher, who often had philosophers as advisors and academic mentors or research colleagues, were less likely to scoff at explication. (And, indeed, no philosopher that I know to date has so scoffed.)

I left South Asian Studies as a student to pursue a PhD in philosophy on the topic of translation, largely in the analytic but also in the continental tradition (Ranganathan, 2007). In this project, I found the answer to this mystery of linguistically inclined authors believing themselves to be studying Indian philosophy while interpreting. What I found was that everyone in the Western tradition, whether analytic or continental philosopher or translation theorist, assumed (without question) the linguistic account of thought, according to which thought is linguistic meaning. (Successful translation on this account is about successfully preserving linguistic meaning in translation, which is puzzling given the reality of linguistic diversity.) Some regard this as a recent development since figures like Frege, but it goes back to the Greeks, who had one word for thought, reason, and language: logos. Secondly, famous philosophers in this tradition endorse interpretation as either a default method of understanding or what is necessitated at the boundaries of cross-cultural understanding. ${ }^{\mathbf{1}}$ What is remarkable is that none of these thinkers noticed that it violates basic constraints of reason, even though it contradicts what we philosophers teach in critical thinking 101. But if interpretation is an outcome of the linguistic account of thought, then one has a cultural explanation for this widespread endorsement: it's part of being Western. And, indeed, if thought is the meaning of what one says, then to think is to endorse the conventionalized perspective of one's language. Hence, all explanation by way of thought is thereby explanation by way of the linguistically encoded beliefs of one's culture: interpretation. So the peculiar trend of an over-indexation on linguistics and the widespread adoption of interpretation in Indology is no longer mysterious to me: it's merely a continuation of what we could call the West: the intellectual tradition connecting contemporary Western philosophy back to its ancient Greek roots. 
The sad part of all this is that it significantly undermines scholarship. Competent reviewers and scholars explicate the perspectives of those they may not agree with and offer feedback of a non-question-begging, formal sort. This activity is in keeping with the requirements of reason. As disagreement is par for course in explication, explicators don't assume that disagreement is a sign of scholarly trouble: reasoning is about converging on what we can disagree about! Interpreters violate reason and expect everyone to agree with them and get upset when authors say things they disagree with. In Indology, this is usually reified and occluded by the expectation that credible scholarship can't be idiosyncratic; it has to represent the conventionalized beliefs of authors in the field. But this is nothing but interpretation, which creates a monolithic literature that tracks not philosophy but the Eurocentric assumptions of its creators. And indeed worth noting is that interpretation itself is a characteristically Western mode of explanation: there is nothing necessary or universal about it, and as it violates basic constraints of reason, it is patently unnecessary. Yet it persists, and this might be because it provides cover for the privilege of those who engage it.

So as to not violate basic constraints of reason, I'm sticking with explication, and with this method, we'll see that idealism is ironic in the Indian tradition, exactly where the interpreter finds idealism. But for now, it's worth noting how destructive interpretation is. It leads to three outcomes:

1 A failure to explicate but interpret leads to the bleaching of divergent Indian moral philosophical views from conventional accounts.

2 Using a methodology that is mentalistic, interpretation, that can only make sense of what is already believed by the interpreter, leads to the projection of a mentalistic worldview on Indian thinkers as the mentalistic methodology of interpretation is itself projected onto Indian thinkers. 
3 The interpreter's inability to appreciate disagreement leads the interpreter to ignore what contradicts their position (say, Indian criticisms of idealism) and rather identify and display what they agree with (which, in this case, would be the criticized idealist positions). Arguments against idealism would hence seem like arguments for idealism to the interpreter.

Indian philosophers would hence appear impractical (as their views on politics and morals are erased from view) but also somewhat irrational as what remains is a mentalistic criticism of ordinary experience with no discernible alternative. Orientalism arises merely from (1). But (2) and (3) are the icing on the cake. And all this arises from the fateful error of treating truth, or what one takes to be true, as a constraint on intelligibility.

\section{Obvious candidates for Indian idealism}

There are famous examples of Indian philosophy that are usually brought up in discussions about idealism. The examples are Advaita Vedanta, Yogācāra Buddhism, Kashmiri Śaivism and the Yogavāsiștha. Importantly, they all buy in to and entail some version of the two-truths doctrine. And, predictably, mentalistic explanation is as a rule part of their account of conventional or worldly truths (of the sort $x$ believes $p$ ) and not absolute truths $(p)$.

\subsection{Advaita Vedānta}

The Advaita position, as we find going back to the Ādi Śankara (eighth century CE), is in some ways a derivative of an earlier view we find in Sānkhya, which has decidedly materialistic elements, and Yoga, which emphasizes the centrality of personal choice in the construction of experience. In the Sānkhya Kārikā, reality is largely explained by the evolution of nature (prakrti). Even our sense of choice and experience are explained by causal connections of natural events. Personal individuality is an abstraction we call in to individuate experiences. However, 
the contents of these personal experiences are entirely epiphenomenal. Upon the realization of the distinction between persons and nature, one's own continuity as an individual is no longer possible. The Yoga Sütra begins with proposing that we have a choice to either treat $p$ as the object of inquiry or identify with mental phenomena, as when we conflate this with 'I believe that p.' This identification with the content of reflection leads to a life of pathology that is cured by treating the thought as something to be controlled. Sankara argues that individuality is a result of a superimposition of the subjectivity of the self onto the objects of awareness (Śankara Vedānta Sūtra Bhāṣya, preamble), constructing a derivative, erroneous reality characterized by avidya (ignorance). For Śankara, however, the Self is qualitatively identical across individuals. He hence identifies the Self with the substance Brahman: expansion, growth. Correlatively, anything that can individuate us is reducible to the realm of propositional content. But it is via this confusion of the content of thought with the Self that our individuality is born. Our own liberation thus involves getting over our own notion of individuality and un-conflating ourselves with the contents of reflection. Nothing in this picture is idealistic: the basic facts of natural propositional content and a Self that can be superimposed on such propositional content to construct an ersatz reality of 'I believe that $p$ ' is, if anything, a criticism of the mentalism of ordinary experience.

The Self, in Śankara's account, has the trait of knowledge, and the Upanișad formula that Brahman is satyajñānānantam (Taittirīya Upanishad 2.1.1) - truth, knowledge, and the infinite or bliss - seems like idealism only if we reject and ignore the tradition's account of knowledge as a function of practical reason and if we assume, interpretively, that knowledge is a mental function. Yet in this tradition, on which Śankara builds, the model of yoga (discipline) is called upon to account for knowledge; accordingly, we know ourselves when we are able to engage and responsibly control various elements of our life (our senses, our mind, and our body) for the sake of the Self (Katha Upanișad). This is a practical account of knowledge in which mentalistic reductions of knowledge are criticized: knowledge is reducible to the Self once it takes responsibility for the mind and body. Later this will be formalized in Patañjali's Yoga Sūtra. 
Śankara says things that are in tension with the practical orientation of Vedānta. In his commentary on the Bhagavad Gittā, he recommends that we move away from questions of dharma (ethics) and thinking about ourselves as an agent as this leads to and furthers our identification with individual experience (Gîtā Bhăsya 4:21). But the problem here is not that the knowledge of the self is impractical, but that ethics is, in his account, a workaround for the confused self, designed to regulate selfish desires, and liberation takes us away from this selfish individuality (Gìtā Bhāṣya 2.11). So to give up on ideals of agency and ethics in Śankara's account is not to give up on the blameless and dutiful activity of Brahman that doles out karmic consequences in accordance with the merits of individual choice (Vedānta Sütra Bhāṣya II.i.34). It is rather to give up on the confusion of individuality that comes about by superimposing the Self on our contents of experience.

But there is a long tradition of reading Advaita Vedānta as idealistic, and it stretches back to comments on his predecessor Gauḍapāda. For Gauḍapāda, ordinary illusory states of existence are indeed explained by the operation of the mind. But this is not the final story in the Advaita account but part of the illusion to be overcome. And we see this tendency to treat the mind as the source of the problem in antecedent works, such as the influential commentary by Gauḍapāda, the Māṇdūkya Upaniṣad Kārikā. As one commentator opines, according to Gauḍapāda,

The world of duality is nothing but a vibration of the mind (manodrśya or manaspandita). The pluralistic world is imagined by the mind (samkalpa) and this false projection is sponsored by the illusory factor called $m \bar{a} y \bar{a}$. The origination of the individual soul, which experiences the world of duality, is figurative.

\section{(Jagannathan, n.d.)}

There are two parts to this gloss. The first is consistent with Yoga: ordinary understanding is a citta vrtti (mental vibration) according to the Yoga Sütra (I.2). Yoga is not idealism as it treats knowledge and reality as a function of personal responsibility, not the mind or body, which are to be controlled. The second part, however, might seem like idealism as it gives an explanation of 
the imagined world as mental. Yet it is worth noting that this is an error theory: it is not an account of reality. So mind here plays a role in accounting not for what is real, but for what is unreal, and it does not play a role in accounting for knowledge, but rather ignorance and deception. We might call this Advaita Vedānta 'ironic idealism' - it is idealism not in the service of knowledge or reality, but ignorance and illusion.

Yet famous Advaitins have identified Śankara and the tradition as making a case for idealism. The most salient example is Sarvepalli Radhakrishnan (1888-1975), second president of India, and Spalding Professor of Eastern Religion and Ethics at the University of Oxford (1936-1952). Radhakrishnan was an avowed Advaitin whose Hibbert lectures at Oxford were published under the title of An Idealist View of Life (Radhakrishnan, 1932). Radhakrishnan's view is that in reality we are one, this oneness is idealist, and ethics is about overcoming the illusion of our separateness (views Ward, noted earlier, repeats wholesale). How does a famous, educated, and intelligent Indian thinker come to identify a Advaita Vedānta, better accounted for as ironic idealism, as a positive idealist doctrine?

I think we have to acknowledge that Radhakrishnan writes within the colonized space of Indian philosophy - an interpretive space as opposed to an explicatory space - where the intelligibility of an Indian position rests upon it being similar to or a minor departure from prominent positions of the European tradition. At the time, Hegel derived, British Absolute idealism was dominant and would have constituted the philosophy of the educating generation that spawned Radhakrishnan. It is hence unsurprising that Radhakrishnan should try to emulate a humanistic idealism as a way to keep up with the political current of the West. But this move is nothing but interpretation, and the colonial context leaves several markers. First, Radhakrishnan (and others) can be observed attempting to graft a humanistic ethic on Advaita Vedanta. This is a remarkable departure from the tradition, which was un-anthropocentric, but in keeping with the European tradition, especially at this juncture (De Smet, 1968). Second of all, he attempts to argue that moral concern arises from our substantial unity - we care for others because we appreciate that, at base, we are identical ( 
historical Advaitins like Ādi Śankkara, who argued that ethical concerns that regulate desiring or selfish behavior supervene on ignorance and that the liberated person moves away from moral questions (a position we find in the Sänkhya Kārikā too). The matter is slightly different for later authors (some named 'Śañkara') writing in times proximate to Western colonialism (Peetush, 2017). But Radhakrishnan's ethics also takes a page out of Bradley's ethics. As W. Mander, author of British Idealism notes, in 'its very broadest terms Bradley suggests that we may find the end of all action in self-realization. The fundamental issue of ethics is not what we do but what we are' (Mander, 2011: p. 185). Radhakrishnan's emphasis on our substantial unity as Brahman as a source of ethical insight is in keeping with this and other European idealisms. But ironically, this idea that ethics is about self-actualization is the very opposite of the view that Śankara espouses. For Śan்kara, we need to embrace our latent freedom, and this involves doing away with the crutch of ethics.

Radhakrishnan also further draws on the Hegelian strain of the epoch's appreciation of Idealism. He writes:

Idealism in the sense indicated concerns the ultimate nature of reality, whatever may be its relation to the knowing mind. It is an answer to the problem of the idea, the meaning or the purpose of it all. It has nothing in common with the view that makes reality an irrational blind striving or an irremediably miserable blunder.

(Radhakrishnan, 1932: p. 15)

Idealism here is dialectic, pursuing ideas not as a matter of fancy but as the unfolding of reality. It is even tempting to read this as an attempt to draw on the Indian tradition, but there is an important distinction. In the case of the Indian tradition, no one obvious or salient treats ideas as the main point of existence. Reality (not the topic of ironic idealism) is often regarded as perfect on the Indian account and in need of no direction or motivation: it is rather the source of normativity. Rather, the point of reality is often depicted as structured by values and norms - 
dharma, mokșa. We find this affirmed in countless sways in the Indian tradition, when Buddhists, for instance, call the actual constituents of reality 'dharmas,' Jains identify the basic cosmic force of motion as Dharma, Vedāntins such as Rāmānuja call knowledge dharma-bhūta-jñāna (understanding of the moral valence of things), and in the earlier Vedic tradition, we find out that reality was governed by rta (the cosmic normative force) - also reaffirmed in the Yoga Sütra (I.47-8). So, for instance, the ontological realists, Vaiśeșika theorists, who give importance to the enumeration of categories and things treat the entire exercise as an exploration of dharma, as per the opening lines of the Vaiśeșika Sūtra. Understanding ideas is hence of derivative importance, for what gives value and purpose is thought to be not the ideas, but dharma. All this is missed if we interpret Indian philosophy, for then we interpret each use of 'dharma' in accordance with our value system, and the pervasive moral realism drops out of the picture. All this is obvious when we explicate, for we treat 'dharma' and such normative terms as the topic of Indian philosophical explanation, and we find that the theoretical controversy at the heart of competing explanations of such terms is THE RIGHT OR THE GOOD. One might claim that all this is fine, but it's not relevant to Advaita Vedānta, but here, too, we find that on the ultimate account, the motivation of reality cannot be reduced to some further end, such as the pursuit of ideas. Rather, it is depicted as the play of perfection, mere sport (Śañkara Vedānta Sūtra Bhāṣya II.1.33). So in this account, too, reality cannot be explained as goal oriented, in pursuit of the idea. It's just for fun! Radhakrishnan's account of idealism, however plausible or interesting it may be, has no grip on the Indian tradition.

\subsection{Yogācāra Buddhism}

The second obvious candidate for Indian idealism is Yogācāra Buddhism, originating with the works of the philosopher Vasubandhu, which has also been called 'mind only' Buddhism. The labeling is enough to convince us that the school must be a version of idealism, as it claims that there is only mind. But here, too, we encounter the distinction between two varieties of facts, and 
hence, ironic idealism as a criticism of provisional truth. Ironic idealism identifies mind as the ground not of reality or knowledge, but of an ersatz reality and illusion. The origins of the notion that Yogācāra is a form of idealism go back to claims of Vasubandu, as we find in his influential Twenty Verses, that for all beings except for Buddhas and advanced bodhisattvas, the three realms make up the universe and the contents of the three realms is 'only appearance' (vijñaptimātra). It is worth noting that already in this formulation, we have an inkling of ironic idealism - idealism as an explanation not of reality and knowledge, but of some state of error, occupied by those who are not Buddhas or advanced bodhisattvas. Indeed, of late, some commentators reject identifying Yogācāra as a form of idealism (Lusthaus, 2019; Gold, 2018). With respect to later thinkers in this school, determining a clear commitment to idealism is not

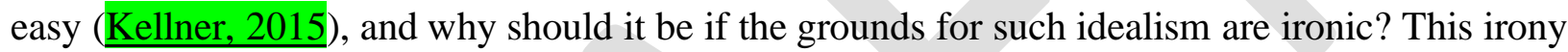
comes on full display in the work of the subsequent author Kamalaśîla, who argues that if Vasubandhu's argument against the reality of external objects is sound, then the same type of argument can be applied to the awareness of such conclusions and to cognition itself (Arnold, 2015: p. 392). As Dan Arnold notes, in this account, it is mental content that is the real problem (Arnold, 2015: p. 390). This is a move in keeping with a mental eliminativism, not idealism. But all this seems like idealism for reasons (2) and (3) listed earlier.

\subsection{Kāśmīra Śaivism}

A prime candidate for Indian idealism is Kāśmīra Śaivism. Kāśmīra Śaivism, stretching back to philosophers such as Abhinavagupta (end of first millennia CE), is a kind of Advaita position, though not explicitly a form of Vedānta. Accordingly, the only reality is Śiva (the Indic god of destruction); the primary self is Śiva. Individuality, ordinarily understood, is depicted as an illusion. According to two leading figures in this tradition, Utpaladeva and Abhinavagupta, those who transcend the illusion of individuality are compassionate and altruistic. But this concern for others is not motivated by others' suffering as we find in Buddhism, but one's own bliss 
(ānanda) (Ratié, 2009). There are unusual features of this monism. Perhaps the more salient feature of this position is that Śiva, the ultimate self, does everything through the goddess Śakti (power). The one in this account, on further inspection, is more than merely Siva.

The Kāśmīra Śaivism scholar David Peter Lawrence notes that the motivation for identifying Kāśmīra Śaivism as a kind of idealism comes from observing Utpaladeva and Abhinavagupta's prakāśa arguments of the that no artha (thing, value, meaning) can exist without prakāśa, which he translates as something like bare 'awareness' (personal correspondence - for Lawrence's excellent work on this topic see Lawrence, n.d.). If one consults the Monier Monier Sanskrit English Dictionary, however, the primary meaning of prakāśa is 'visible, shining, bright' or 'clear, manifest, open, public' (Monier-Williams, 1995: p. 653). Put this way, nothing can exist without its inclusion within a public sphere where it is known. That lends itself not to an idealist reading as we find in Berkeley, where to be is to be perceived, but rather an ethical reading that things that exist have to be known; otherwise, they are destroyed. This fits more clearly with the classical images of Śiva as the destroyer, who withdraws his senses and, with eyes closed, engages in meditation. Destruction here is a matter of ignoring what is real, and in this ignoring, one acts in a manner that does not take into account ignored objects, leading to their demise. Śiva's self-recognition, an essential theme of this philosophy, is part of how Śiva does not destroy himself. Treating Kāśmīra Śaivism as something to be explicated within the continuity of Indian philosophical disagreement does not entail that it is a version of Berkeleyan idealism. Of course, if we interpret Indian philosophy, we can bring this awareness of the Berkeleyan option to our reading of Utpaladeva and Abhinavagupta, and we would be inclined to see it that way, as the alternative Śaiva account (where destruction plays a central role in explanation) is not part of our Eurocentric awareness but also not accounted for in the Berkeleyan reading. Berkley's God is one who preserves by awareness; Siva is the God who destroys by benign neglect.

What can we make then of Isabelle Ratié's claim that freedom is at the heart of an absolute Idealism in Utpaladeva's and the Kāśmīra Śaivism work? She writes: 
The Śaivas thus argue that the only way to account for our most ordinary experiences and the synthesis that they involve is to admit that all momentary cognitions are various aspects of one single lasting consciousness. But they do not content themselves with establishing that this consciousness is unitary: their goal is to prove that it manifests itself in the form of the universe, that is, as insentient objects and as conscious beings that are limited in space and time. In other words, they want to establish a kind of absolute Idealism, and they share with the Buddhist Vijnānavādins (the upholders of the Vijnānavāda, 'the thesis that [everything is] consciousness') the conviction that perceived objects, which we ordinarily believe to be external to consciousness, are in fact mere aspects or appearances ( $\bar{a} k \bar{a} r a)$ taken on by consciousness, just as the world of our dreams.

(Ratié, 2015: p. 443)

For starters, Vijnānavāda (consciousness only theory) is another name for the Yogācāra school, which is a form of ironic idealism. The similarity of the Kāśmīra Saiva position to Vijnānavāda is evidence against it being a form of idealism. Secondly, consciousness is not the basic explanation in the Saiva account: it is Siva that is the ultimate explanation. The recognition of consciousness's variegation against this common Self is an error theory, in part a function of Śiva's destructive activity. And to the extent that idealism plays a role in this error theory, it is ironic, for the ultimate story is not that everything is consciousness, but that it is Siva. Siva transcends consciousness in his self-recognition in this account - for Siva not only knows but is known. Of course, we could interpret the Kāśmīra Śaivism position as idealism, given our beliefs informed by the Western tradition, but what would disappear from all this is exactly what is foreign to the Western tradition: Śiva.

\section{Indian idealism?}


Although there is no unanimity about what 'Idealism' means and although there are different shades of Idealism, Idealists generally maintain that there can be no object of knowledge without knowledge: consciousness is not only the prius of reality, consciousness is to be presupposed as the essence, the substance, the reality behind all things of our experience. In short, Idealism considers mind or idea or spirit as the projector of this worldly phenomenon, and emphasizes that it does not exist independently of the mind or idea.

(Chenet, 2015: pp. 471-472)

This is from François Chenet in his article 'The Nature of Idealism in the Mokṣopāyaśāstra/Yogavāsiștha.' The article provides an overview of the two related texts. The later text is the Yogavāsiștha, which contains within it an earlier kernel, the Mokșopāyaśāstra (The Treatise on the Path to Liberation). The Yogavāsisțtha is a discussion between the sage Vasiṣtha and Rāma of the Rāmāyana (one of India's two major Sanskrit epics). The dialogue centers around many issues in philosophy but most importantly how to live best: Rāma takes the advice to heart and returns to his kingly duties and uses the advice to be an excellent leader.

Chenet notes that the philosophy of these texts draws heavily from the previous candidates for idealism, and moreover, he appears to equate idealism with the 'mind only' view that we learn about from Yogācāra Buddhism, used here also in a similar way: as a criticism of the external world, conventionally understood. Put this way, idealism resonates with the view Chenet describes: the idea that the experience is a projection of mind. But this characterization is problematic as an account of the options of idealism. Objective idealism would be difficult to make sense of in this account: for the objective idealist, reality is mental insofar as it is a reflection (not a projection) of ideal objects. The projective theory is rather more consonant with a subjective idealism. Moreover, we could easily turn this supposed idealism, or mind-only idealism, into a patently materialist position. We would merely need to define the mind or consciousness as a neural or material state. Then phenomena would be merely epiphenomenal 
and not representative. And this conversion into materialism leaves intact the wording of idealism as described earlier,. Already we have noted that the Yogācāra, mind-only position is not straightforward idealism but ironic idealism, and hence, the Yogavāsiștha would also be if it merely took over this doctrine.

Chenet himself shows the position of the Yogavāsiștha is not idealism but ironic idealism. He writes: 'The concept of the unreality of the world is strongly emphasized by considering the world as a mere ideation of the mind' (Chenet, 2015: p. 474). Idealism is not the view that the world is unreal - that's nihilism. Idealism is the view that reality or knowledge is mental. To characterize this nihilism as idealism is ironic. But there is more. As Chenet notes, the Yogavāsiștha heaps scorn on the idea that fate or destiny (the causes beyond our control) shapes our lives. Vasișțha rather emphasizes the centrality of personal effort (pauruṣa, puruṣakāra, purușa-yatna, YV III.62). He writes, 'Nothing is left to fate or chance. Our destiny is not mapped out for us by some other agency but by our own thought; control thought and you control destiny' (Chenet, 2015: p. 477). Here, we find a dose of yoga, as we find earlier in Patañjali's Yoga Sütra: controlling thought is essential to controlling our lives as thought, or mental phenomena, are analyzable into the contents of the external world, and hence, to actualize ourselves involves taking responsibility for our life and not merely living passively in deference to mental content that we have propositional attitudes (of fear, hope, anger, desire) to but by engaging with the things that we can think about. This is controlling thought. As Patañjali notes, mind hence recedes back into nature and, we are thereby free, as actualized agents (YS I.2). But this is not idealism either, for mind becomes reduced out of the picture of the actual account of reality. Chenet himself sees Vasiștha bringing us to this clarity about idealism and yoga:

So what is meant by the term 'Idealism' [mind-only] in the Yogavāsiștha? Idealism is not to be taken only in an epistemological sense as mentioned above, because, according to Vasiștha, Idealism is the view which maintains (1) the autonomy of consciousness, so that (2) person is endowed with an absolute freewill which enables him to mould his own destiny, (3) through the control of his imaginative faculty. 
(Chenet, 2015: p. 477)

This position is fairly close to Patañjali's yoga. It's also far removed from a metaphysical or epistemic position that could be called idealism. It's a theory of practical rationality. The idea that reality is mental, something to be merely observed or believed, is exactly what rational action militates against. It brings us into our own as individuals responsible for our destiny, for it treats mental content to a deflationary axe.

\section{Objections}

Positions that are ironically idealistic provide a two-level analysis of the facts. At the mundane level, the facts are conceived of as mental, but at the higher, more insightful level, they are not. Distinguishing between these two levels of facts is a rebuke and criticism of the mundane level of facts as a psychological construct. Interpretive approaches common in Indology ignore these two levels as they themselves are committed to reducing all thought to the provisional level: the beliefs of the interpreter. There is nothing metaphysically necessary about this reduction, for as noted, the two varieties of facts ( $p$ and $x$ believes $p$ ) are logically distinct. Hence, those who interpret are not metaphysically compelled into this conflation. And yet, owing to the adoption of a methodology that overrides reason by equating understanding with such provisionally true claims (about the psychology of the interpreter), the interpreter does not reason. They rather project onto the world their assumptions. Their paradigm is the fitting subject of the Indian ironic idealist's criticism. Interpreters participate in an ersatz reality of mind only.

It does not help that defenders of interpretation are deeply confused by virtue of interpretation, and this confusion leads to several further high-horse errors. In violating the basic constraints of reason that confuse reason with what one takes to be true, interpreters beg the question of the proper methodology of understanding (which is a fallacy), assuming that there can be no other, and then accuse others who claim to be departing from interpretation of 
themselves offering an alternate interpretation (tu quoque, which is also a fallacy). As perhaps the most rhetorically persuasive interpreter argues,

A person who believes he is free of prejudices, relying on the objectivity of his procedures and denying that he is himself conditioned by historical circumstances, experiences the power of the prejudices that unconsciously dominate him as a vis a tergo.

(Gadamer, 1996: p. 360)

But the explicator who endorses the objective method of logical validity as a tool of understanding does not deny their own biases; they adopt a method of understanding in which what is understood is not an entailment of their biases. It is the interpreter, in contrast, who adopts the procedure of understanding as an entailment of their biases, and nothing is gained by rendering one's biases explicit so long as one interprets. The interpreter operates in a samsāra (vicious circularity) of avidya (nescience) by insisting that all understanding is referable back to their own beliefs. Indian criticisms of ordinary life as ironically idealistic apply to the interpreter who trades in provisional truths as the content of explanation.

But one might pose an objection that the analysis provided here sells idealism short. Sure, if all facts are of the provisional ' $\mathrm{x}$ believes p' sort, then the facts would be idealistic, and knowledge would be correspondingly idealistic. But what of the ultimate facts, $p$ : couldn't these facts themselves be ideal? With respect to the Indian examples that we considered, we find no reasons or arguments provided by the philosophers themselves to draw the conclusion that the absolute facts are ideal. Mind is consistently criticized as an artifact of the provisional approach to reality. I suspect one reason that Indian philosophers did not argue that the actual, nonprovisional facts are mental, or that mind has any important role in understanding these facts, is that they wanted to clearly distinguish the two varieties of facts, and keeping mind out of an account of the absolute facts is to this end. This, of course, renders the absolute truths somewhat mysterious if one assumes that understanding is a mental exercise. But if it's an exercise of the 
responsibility to critically reason, and if this activity is an exercise not of belief but of practical rationality, then we have a way to understand the ultimate facts in terms of choice and moral notions. Even in the case of Śankara, who criticizes ethics and agency, we find that in the final analysis, the absolute truth has to do with the freedom that the Self has to either identify (erroneously) with the content of experience or to be independent (as we would need to be if we were engaging in actual reasoning). And indeed, it is difficult to see how reasoning could be a matter of belief, for this would lead us back to interpretation.

\section{Conclusion}

In this chapter, I have argued that the common positions that are treated as salient examples of idealism in the Indian tradition are actually examples of ironic idealism. Ironic idealism is the position that there are two varieties of facts - a contingent or provisional variety (contingent upon choice) and an absolute variety - and that idealism characterizes the provisional variety of fact. The distinction of the two truths consists in a criticism of the provisional variety of facts: they seem to be the final story, but they are not. Idealism hence plays a role in an error theory in these positions and is hence ironic: for it's not accounting for actual reality or knowledge where our responsibility to our life resides, but the fictionalized, ersatz aspect of our life that arises from uncritically identifying with experiences. These are facts in the way that ' $x$ believes $p$ ' can be a fact. Can we nevertheless understand ironic idealism as a kind of idealism? The extent to which we are inclined to be positive about this will depend on how much room we give absolute truth in our appreciation of these Indian options. 


\section{Note}

\section{Bibliography}

Arnold, D. (2015) The Place of Philosophy in Kamalaśîla’s Steps of Cultivation. In: Ganeri, J. (ed.) Oxford Handbook of Indian Philosophy. Oxford, Oxford University Press, pp. 379399.

Chenet, F. (2015) The Nature of Idealism in the Mokșopāyaśāstra/Yogavāsișțha. In: Ganeri, J. (ed.) Oxford Handbook of Indian Philosophy. Oxford, Oxford University Press, pp. 469485.

Davidson, D. (1986) A Coherence Theory of Truth and Knowledge. In: Le Pore, E. (ed.) Truth and Interpretation: Perspectives on the Philosophy of Donald Davidson. Cambridge, Blackwell, pp. 307-319.

De Smet, R. V. (1968) The Indian Renaissance: Hindu Philosophy in English. International Philosophical Quarterly, 8 (1), pp. 5-37.

Davidson, D. (2001) On Saying That. In: Inquiries into Truth and Interpretation. Oxford, Claredon Press, pp. 93-108.

Derrida, J. (1981) Plato's Pharmacy. In: Johnson, B. (trans.) Dissemination. Chicago, University of Chicago Press, pp. 61-172.

Frege, G. (1988) Thoughts. In: Salmon, N. U. \& Soames, S. (eds.), Geach, P. \& Stoothoff, R. H. (trans.) Propositions and Attitudes. Oxford, Oxford University Press, pp. 33-55.

Gadamer, H. G. (1990) Culture and the World. In: Schmidt, D. J. (ed. \& trans.) Hermeneutics and the Poetic Motion Translation Perspectives V. Binghamton, SUNY Press, pp. 11-24. Gadamer, H. G. (1996) Truth and Method. Translated by Weinsheimer, J. \& Marshall, D. G. 2nd Revised Edition. New York, Continuum. J.C.B. Mohr (Paul Seibeck).

Gold, J. C. (2018) Vasubandhu. In: Zalta, E. N. (ed.) The Stanford Encyclopedia of Philosophy. Available from: https://plato.stanford.edu/archives/sum2018/entries/vasubandhu/. 
Guyer, P. \& Horstmann, R.-P. (2015) Idealism. In: Zalta, E. N. (ed.) The Stanford Encyclopedia of Philosophy. Available from: https://plato.stanford.edu/entries/idealism/.

Heidegger, M. (2010) Logic: The Question of Truth. Translated by Sheehan, T. Studies in Continental Thoguht. Bloomington, Indiana University Press.

Jagannathan, D. (n.d.) Gauḍapāda. In: Fieser, J. \& Dowden, B. (eds.) Internet Encyclopeadia of Philosophy. Available from: www.iep.utm.edu/gau\%E1\%B8\%8Dapad/ [Accessed 2019]. Kellner, B. (2015) Providing Idealism Dharmakīrti. In: Ganeri, J. (ed.) Oxford Handbook of Indian Philosophy. Oxford, Oxford University Press, pp. 307-326.

Lawrence, D. (n.d.) Abhinavagupta. In: Oxford Bibliography Online. Oxford, Oxford University Press.

Lorenz, H. (2009) Ancient Theorie of Soul. In: Zalta, E. N. (ed.) The Stanford Encyclopedia of Philosophy. Available from: https://plato.stanford.edu/archives/sum2009/entries/ancientsoul/.

Lusthaus, D. (2019) What Is and Isn’t Yogācāra. In: Muller, A. C. (ed.) Resources for East Asian Language and Thought. Available from: www.acmuller.net/yogacara/articles/intro.html.

Mander, W. (2011) The Idealist Ethic of Social Self-Realization. In: (ed.) British Idealism: A History. Oxford, Oxford University Press.

Matilal, B. K. (1989) Moral Dilemmas: Insights from the Indian Epics. In: Matilal, B. K. (ed.) Moral Dilemmas in the Mahābhārata. New Delhi, Shimla, Indian Institute of Advanced Study in association with Motilal Banarsidass, pp. 1-19.

Monier-Williams, M. (1995) A Sanskrit-English Dictionary: Etymologically and Philologically Arranged, with Special Reference to Cognate Indo-European Languages. Greatly Enlarged and Improved Edition. New Delhi, Motilal Banarsidass.

Myers, R. H. \& Verheggen, C. (2016) Donald Davidson's Triangulation Argument: A Philosophical Inquiry. London, Taylor \& Francis. 
Peetush, A. (2017) The Ethics of Radical Equality: Vivekananda and Radhakrishnan's NeoHinduism as a Form of Spiritual Liberalism. In: Ranganathan, S. (ed.) The Bloomsbury Research Handbook of Indian Ethics. London, Bloomsbury Academic, pp. 357-382.

Potter, K. H. (1963) Presuppositions of India's Philosophies. Prentice-Hall Philosophy Series. Englewood Cliffs, NJ, Prentice-Hall.

Quine, W. V. O. (1960) Word and Object. Cambridge, MA, MIT Press.

Radhakrishnan, S. (1914) The Ethics of the Vedanta. International Journal of Ethics, 24 (2), pp. $168-183$.

Radhakrishnan, S. (1932) An Idealist View of Life. New York, The Macmillan Company. Ranganathan, S. (2007) Translating Evaluative Discourse: The Semantics of Thick and Thin Concepts. Diss. York, York University, Department of Philosophy. Available from: www.collectionscanada.gc.ca/obj/thesescanada/vol2/002/NR68573.PDF.

Ranganathan, S. (2017a) Patañjali's Yoga: Universal Ethics as the Formal Cause of Autonomy. In: Ranganathan, S. (ed.) The Bloomsbury Research Handbook of Indian Ethics. London, Bloomsbury Academic, pp. 177-202.

Ranganathan, S. (2017b) Western Imperialism, Indology and Ethics. In: Ranganathan, S. (ed.) The Bloomsbury Research Handbook of Indian Ethics. London, Bloomsbury Academic, pp. 1-122.

Ratié, I. (2009) Remarks on Compassion and Altruism in the Pratyabhijñā Philosophy. Journal of Indian Philosophy, 37 (4), pp. 349-366.

Ratié, I. (2015) Utpaladeva and Abhinavagupta on the Freedom of Consciousness. In: Ganeri, J. (ed.) Oxford Handbook of Indian Philosophy. Oxford, Oxford University Press, pp. 438468.

Thakchoe, S. (2011) The Theory of Two Truths in India. In: Nodelman, U. \& Zalta, E. N. (eds.) Stanford Encyclopedia of Philosophy. Available from: http://plato.stanford.edu/entries/twotruths-india/. 
Ward, K. (n.d.) Keith Ward on Idealism in Eastern and Wester Philosophy. In: Edmonds, D. \& Warburton, N. (eds.) Philosophy Bites. Available from:

https://hwcdn.libsyn.com/p/c/a/3/ca3614a2d40a2dc6/Keith_Ward_on_Idealism.mp3?c_id $=1779575 \&$ cs_id $=1779575 \&$ expiration $=1550598740 \&$ hwt $=31459 \mathrm{~b} 51 \mathrm{ae} 19700756823 \mathrm{c} 1$ 53f201fac [Accessed 2019].

For defenses of this procedure, see Gadamer, 1990, 1996, early Davidson on Charity (Davidson, 2001: p. 101, 1986: p. 316) and Quine, 1960: p. 59. Heidegger goes so far as to claim that logic is itself concerned with truth rendering all explanation hermutic or interpretive (Heidegger, 2010). Even Derrida provides arguments that fall within this trend (Derrida, 1981). My colleagues Robert Myers and Claudine Verheggen remind me that the full and mature Davidson moves to an externalist semantics and, moreover, triangulation (Myers \& Verheggen, 2016) - an idea that I have stressed is a basic theme in the Indian tradition. It is true that Davidson moves away from characterizing understanding as interpretation in his later works. 